\title{
Az 1-aril-1H-pirrolok kémiája: alapváz funkcionalizálástól az enantioszelektív fémorganikus katalízisig
}

\author{
MÁTRAVÖLGYI Béla*, HERGERT Tamás, THURNER Angelika és FAIGL Ferenc \\ Budapesti Müszaki és Gazdaságtudományi Egyetem, Szerves Kémia és Technológia Tanszék \\ Budafoki út 8. 1111 Budapest, Magyarország
}

\section{Bevezetés}

A többszörösen szubsztituált 1-arilpirrolok gyakorlati szempontból fontos vegyületek építőkövei. Számos 1arilpirrol-származék mutat antibiotikus, ${ }^{1}$ citosztatikus, ${ }^{2}$ gomba- ${ }^{3}$ és vírusellenes ${ }^{4}$ hatást, specifikus kötődést az 5$\mathrm{HT}_{3},{ }^{5}$ vagy az $5-\mathrm{HT}_{7}$ szerotonin receptorokon. ${ }^{6}$ Ismertek 1-arilpirrol részletet tartalmazó Ca-csatorna blokkoló, ${ }^{7}$ gyulladáscsökkentő (Clopirac), ${ }^{8}$ calmodulin inhibitor, ${ }^{9}$ mineralkortikoid- ${ }^{10}$ valamint benzodiazepin receptoron ható $^{11}$ vegyületek is. A hagyományos szintetikus eljárások azonban gyakran közepes, vagy alacsony termeléssel eredményezik ezeket a célmolekulákat. A pirrol igen könnyen reagál az elektrofilek széles körével, föként C2 szubsztituált terméket eredményezve, azonban az ilyen reakciók során alkalmazott erős savak a vegyület részleges degradációjához, polimerizációjához is vezetnek. Másfelől a helyettesítők (és az elektrofilek) sztérikus hatásait szintén számításba kell venni, ami a szubsztitúció helyzetét erősen befolyásolja. Nitrogénen nagy térkitöltésü csoportot tartalmazó származékok esetében a C3 szubsztitúció aránya jelentősen előtérbe kerülhet. Például 1-aril-1H-pirrol-2karboxaldehid és 1-aril-1H-pirrol-3-karboxaldehid keverékének képződése figyelhető meg a megfelelö 1-aril-1H-pirrolok Vilsmeier-formilezése során. ${ }^{6}$ A $4 H, 6 H$ pirrolo-[1,2 a][4,1]benzoxazepin gyürürendszert tartalmazó vegyület eredeti szintézise aktivált karbonilvegyületek, például etil-piruvát 1-[2-(hidroximetil)fenil]-1H-pirrolra történő savkatalizált C2 helyzetü addícióján és az azt követő, ugyancsak savkatalizált gyürüzáráson alapszik. ${ }^{9}$ A vegyület ilyen módon történő előállításának össztermelése alacsony $(<30 \%)$. Kutatócsoportunk 1-arilpirrolok kémiáját feltáró programja a triciklus (3) fémorganikus úton (2 intermedieren keresztül) történő kialakításának vizsgálatával kezdődött. ${ }^{12}$

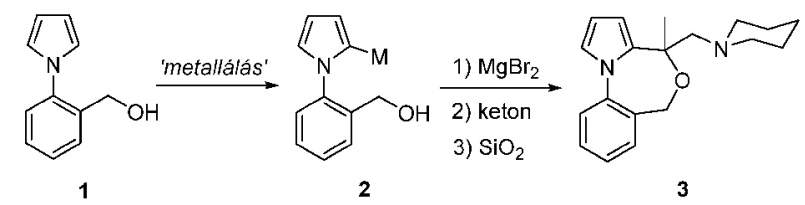

1. Ábra. Benzoxazepin gyürürendszer kialakítása fémorganikus úton (keton: 1-piperidinopropán-2-on)

\section{Eredmények és értékelésük}

\subsection{Az alapváz fémorganikus funkcionalizálása}

$\mathrm{Az}$ kutatómunka kezdeti időszakban a benzolgyürün különböző helyettesítőket tartalmazó 1-arilpirrolok szelektív metallálási lehetőségeit kutattuk, szisztematikusan tanulmányozva az oldószer, a metallálószer és az alkalmazott komplexáns hatását a reakcióra. A vizsgálatok a metallálás mechanizmusának felderítésével indultak (2. ábra).

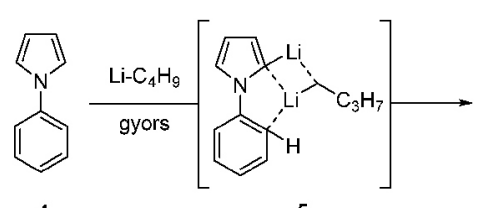

4

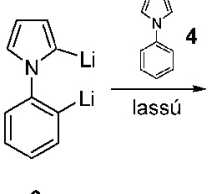

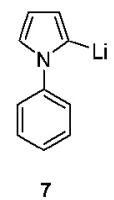

2. Ábra. Az 1-fenil-1H-pirrol (4) lítiálásának mechanizmusa

Időfüggő kísérletsorozatot végezve bizonyítottuk, hogy $\mathbf{4}$ dimetallálása kinetikusan kontrollált folyamat. Kiindulási anyag jelenlétében a gyors reakcióban képződő $\mathbf{6}$ folyamatos transzmetallálódás útján a stabilabb 2-lítio-1-fenil-1H-pirrollá (7) alakul. Az 2-lítio termék (7) képződéséhez optimális reagensnek a kálium-terc-butoxiddal aktivált $n$-butil-lítiumot (LIC KOR szuperbázis) találtuk (THF, $-75^{\circ} \mathrm{C}, 30$ perc, $98 \%$ szelektivitás), mely a BuLi/TMEDA reagensnél rövidebb reakcióidő alatt szelektíven eredményezte a célterméket (DEE/hexán, $0^{\circ} \mathrm{C}, 5$ óra, $45 \%$ szelektivitás). Jól szolvatáló oldószer (például tetrahidrofurán dietil-éter helyett) szintén a termodinamikusan kontrollált (7) termék képződésének kedvez. Az 1-(szubsztituált-fenil)-1H-pirrolok fém-organikus reagensekkel való reakciójában a heteroatomot tartalmazó aromás gyürü és a benzolgyürün elhelyezkedő szubsztituens irányító hatásának együttes tanulmányozására nyílt mód. Modellvegyületeink a hidroximetil-, ${ }^{12}$ metoxi, ${ }^{13,14}$ trifluormetil-, ${ }^{15,16}$ bróm- és klór-,14 fluor-, ${ }^{17}$ metil-, ${ }^{18,19}$ etil-, ${ }^{19,20}$ valamint fenil-csoportokat ${ }^{21}$ különböző helyzetekben tartalmazó 1-fenil-1H-pirrolok voltak. A csoportunk végzett elöször szisztematikus kísérleteket a két, illetve három heteroatomot tartalmazó TMEDA és PMDTA aktiváló és regioszelektivitást befolyásoló hatásának összehasonlítására. ${ }^{13}$ Az 1-(4-metoxifenil)-1 $H$-pirrol lítiálása igen jól szemlélteti, hogy megfelelő ligandummal az egyéb körülmények tekintetében (oldószer, hőmérséklet, koncentráció, reakcióidő) azonosan kivitelezett metallálások regioszelektivitása megváltoztatható (3. ábra). 


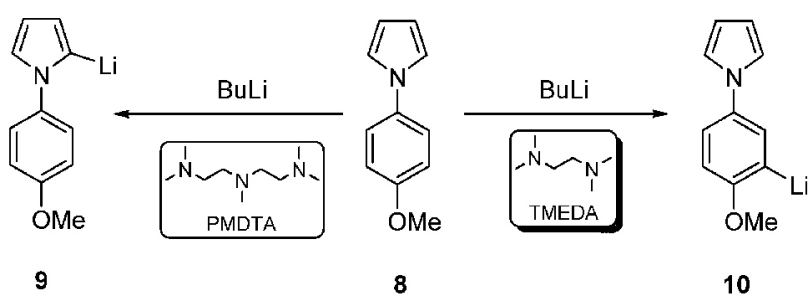

3. Ábra. TMEDA és PMDTA regioszelektivitást befolyásoló hatása

TMEDA jelenlétében a metoxi-csoport melletti orto helyzetben történik lítiálás (10), mivel az átmeneti komplex létrehozásában részt vesz a metoxi-csoport heteroatomja. A három heteroatomot tartalmazó PMDTA-val kialakuló LIC-PMDTA komplexben viszont a lítiumatom, telített koordinációs szférája miatt nem koordinálódik a metoxi-csoporttal, így az 1-(4-metoxifenil)-1H-pirrol (8) legsavasabb hidrogénjének cseréje valósul meg (9).

A metallálási vizsgálatok egy speciális esete volt a kettős funkcionalizálás lehetőségének megvalósítása. A körülmények megfelelő megválasztásával sikerült több származék esetében is mind a pirrolgyürü $\mathrm{C} 2$, mind a benzolgyürü orto helyzetü szénatomjának együttes lítiálását szelektíven véghezvinni, így például dikarbonsav- származékokat közel kvantitatív termeléssel előállítani (4. ábra). ${ }^{14-16,18-22}$

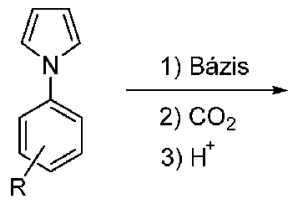

11

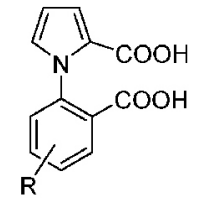

12
$\mathrm{R}=\mathrm{H}, \mathrm{CF}_{3}$, OMe

$\mathrm{Cl}, \mathrm{Me}, \mathrm{Et}, \mathrm{Ph}$
4. Ábra. 1-Fenil-1H-pirrol alapvázú dikarbonsavak előállítása (bázis: 2 ekvivalnes BuLi-TMEDA / BuLi-PMDTA vagy LIC-KOR)

\subsection{Atropizomerek és sóképzéses rezolválásuk}

A benzolgyürün 2-szubsztituált 1-aril-1H-pirrolok metalállásával kapott dikarbonsavak a kiralitás egy speciális formáját mutatták. Szerkezetükből adódóan a két aromás gyürü közötti C-N kötés körüli rotáció a szubsztituensek benzol-gyürü C2 és C6 helyzetében, valamint a pirrolgyürü C2-szénatomján - ütközése révén gátolt. Molekulamodellezési számítások alapján, majd később kísérleti úton is (hőmérsékletfüggő NMR vizsgálatok királis shift-reagens jelenlétében) bizonyítottuk, hogy például 13 dikarbonsav (5. ábra) enantiomerjeinek izomerizációs aktiválási szabadentalpiája $(31,6 \mathrm{kcal} / \mathrm{mol})$ elég nagy ahhoz, hogy a forgási izomerek optikai aktivitásukat normál körülmények között megörizzék, ${ }^{22}$ így e dikarbonsav-származékok az atropizomer vegyületek új képviselőit alkotják.

$\mathrm{Az}$ enantiomerkeverékek elválasztásának (rezolválás) kutatása több évtizedes hagyományokra tekint vissza Tanszékünkön. ${ }^{23}$ A megjelent összefoglaló közlemények részletesen tárgyalják a rezolválási technikákat, ${ }^{24-26}$ valamint a nem-racém enantiomerkeverékek elválasztási lehetőségeit is. ${ }^{27} \mathrm{Az}$ elmúlt években enantiomertiszta vegyületek előállítására igen nagyszámban megvalósított sztereoszelektív szintézisek és királis kromatográfiás eljárások ellenére a racém vegyületek optikai izomerjeinek rezolválás útján történő elválasztása és tisztítása ma is sokszor a legolcsóbb és nagy méretekben a legegyszerübben kivitelezhető módszer. Az eljárás nem igényel extrém körülményeket, vagy drága reagenseket és az alkalmazott rezolváló ágensek a folyamat végén legtöbbször visszanyerhetők. A diasztereomersók kristályosításán alapuló rezolválások kidolgozását ma már számos felismert törvényszerüség és tapasztalati szabály segíti. Mégis a mai napig egy rezolválás kidolgozása rengeteg kísérleti munkát igényel, míg a megfelelő hatékonyságú elválasztást sikerül megvalósítani. Egy új racém vegyület rezolválásakor több tényező ideális összhangját kell megvalósítanunk. Ezek a megfelelő rezolválószer és oldószer megválasztása, valamint az optimális körülmények (mólarány, akirális segédanyagok, hőfok, kristályosítási idő) megteremtése.

A kutatócsoportban előállított atropizomer dikarbonsavak tükörképi izomerjeinek tiszta formában történő előállítására általánosan alkalmazhatónak találtuk a diasztereomersóképzéses rezolválást. A vizsgált racém atropizomerek körében (S)-1-fenil-etil-aminnal (FEA) minden esetben sikerült bizonyos fokú enantiomer-megkülönböztetést elérnünk, de a módszerek körülményei, hatásfokuk és preferált csavarodottságú izomerei az egyes esetekben eltérők voltak. $\mathrm{Az}$ első hatékony rezolválást az 1-[2-karboxi-6-(trifluormetil)fenil]-1H-pirrol-2-karbonsav (13) esetében valósítottuk meg (5. ábra). ${ }^{15} \mathrm{~A}$ legjobb eredményt fél ekvivalens (S)-FEA-nal kaptuk, azonban az etanolban végrehajtott enantiomerelválasztás csak a primer termék átkristályosítását követően adott megfelelő optikai tisztaságú terméket. Az enantiomertiszta 13 dikarbonsavhoz így csak alacsony termeléssel és hatékonysággal jutottunk $(\mathrm{S}=0,2)$.
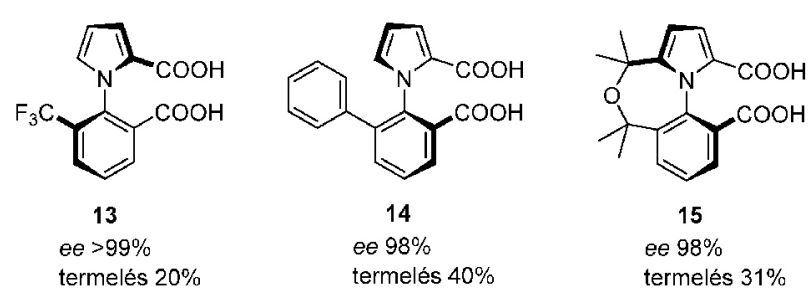

5. Ábra. $(S)$-FEA rezolválószerrel enantiomertisztán előállított 1-fenil-1H-pirrol alapvázú atropizomer dikarbonsavak

A racém 14 és 15 dikarbonsavak rezolválása szintén etanolban végezhető el eredményesen ekvivalens mennyiségü rezolválószerrel (5. ábra). ${ }^{21,22}$ Tiszta enantiomerek az első kristályosítás során nyert sók elbontását követő újbóli rezolválással nyerhetők. Az eljárás közepes hatékonysággal ( $\mathrm{S}=0,39$ illetve 0,3$)$ eredményezi a megfelelő forgási izomereket, azonban érdekes jelenség, hogy ugyanazon konfigurációjú 1-fenil-etil-amin az ellenkező csavarodottságú dikarbonsav enantiomerekkel képez jól kristályosodó sókat, mint a trifluormetilhelyettesítőt tartalmazó $\mathbf{1 3}$ esetében. A tiszta enentiomerek abszolút konfigurációját egykristály- röntgendiffrakciós, illetve cirkuláris dikroizmus mérésekkel határoztuk meg. 
A kutatómunka e stádiumában további célunk az előállított enantiomertiszta atropizomerek hasznosítása volt, részben önmagukban, illetve karboxil-csoportjaiknak átalakításával kétfogú ligandumokként vagy organokatalizátorokként. Az eredmények alapján az optikailag aktív vegyület többlépéses szintetikus módosítása racemizáció bekövetkezése nélkül megvalósítható (magas rotációs energiagát), azonban a kidolgozott enantiomer-elválasztások alacsony hatékonysága ezt nem tette multigrammos méretben kivitelezhetővé.

Szintetikus szempontból igen nagy jelentőségü a $\mathbf{1 3}$ trifluormetil-helyettesített származék, mivel karboxil-csoportjainak reaktivitása merőben eltérő. Ez két tényező eredője: egyik a benzolgyürün lévő trifluormetil-csoport elektronszívó hatása, amely növeli az elektronhiányos állapotot a hozzá képest meta helyzetü karbonil szénatomon, másik a pirrolgyürű elektronküldő tulajdonsága, mely csökkenti a heterociklushoz kapcsolódó karbonil szénatom parciális pozitív töltését, ezáltal szelektív átalakításokat lehetővé téve az azonos funkciók között. Ezeket figyelembe véve célunk egy hatékony sóképzéséses rezolválás kidolgozása volt az optikailag aktív 13 előállítására. A körülmények (rezolválószer, oldószer, idő) részletes vizsgálata eredményeképp sikerült (R)-2-fenilglicin-metil-észter rezolválószerrel (FGMe) egy kimagasló hatékonyságú eljáráshoz jutnunk. ${ }^{28}$ Alig két órás kristályosítást követően közel enantiomertiszta dikarbonsavat tartalmazó só (ee 97\%) szürhető ki az elegyből 80\%-os termeléssel. Érdekesség, hogy a kristályosítás idejének növelése az optikai tisztaság drasztikus csökkenéséhez vezetett. Az optimális kristályosítási idő és az enantiomertisztaság csökkenés folyamatának meghatározása érdekében kísérletsorozatot végeztünk, mely alapján megállapítható hogy 2 hét után gyakorlatilag racém termék izolálható (330 óra után az ee mindössze $5 \%, 6$. ábra).

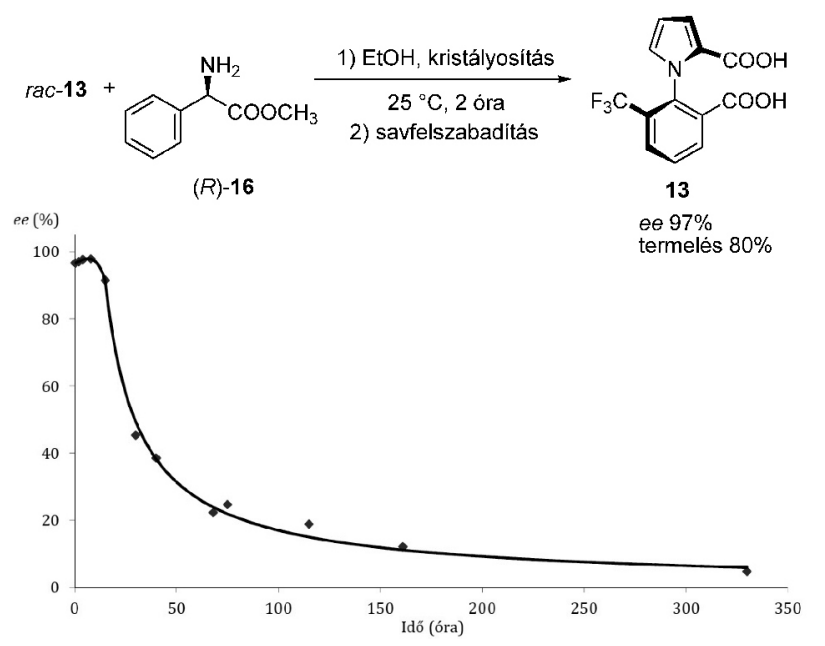

6. Ábra. A 13 hatékony rezolválása ( $R$ )-FGMe-rel; a diagramon a diasztereomersóból nyerhető dikarbonsav enantiomertisztaságának időbeni alakulása látható (független kísérleti pontok, ee meghatározása királis AD-H oszlopon HPLC módszerrel)
A jelenség hátterében a rezolválószer adott körülmények között bekövetkező racemizációja áll. Ez az első ránézésre igen negatív jelenség, azonban elönyösen kihasználható, ha a 'fordított' rezolválás esetében gondolkodunk. Az új rezolváló ágensek kutatása igen nagy jelentőséggel bíró kutatási terület az atropizomer vegyületek körében is. E kutatási irány és vegyületeink hasznosíthatósági vizsgálatának célja eredményeképp $\mathbf{1 3}$ dikarbonsav rezolválószerként való alkalmazását is vizsgáltuk.

A klasszikus rezolválási módszerekkel elméletileg is csak a racém anyag fele nyerhető ki, a rossz izomer veszendőbe megy. Vannak azonban olyan kombinált módszerek, amikor a nem hasznos izomer racemizálása és a számunkra szükséges enantiomer kinyerése egy edényben megvalósítható akár kinetikus (dinamikus kinetikus rezolválás), akár termodinamikai kontroll (másodrendü aszimmetrikus transzformáció) érvényesülése mellett. Ezekkel a módszerekkel tehát elvileg a racém anyag teljes mennyisége a számunkra szükséges enantiomerré alakítható. A másodrendü aszimmetrikus transzformáció egy spontán epimerizációval egybekötött kristályosítás. A körülmények helyes megválasztásával elérhető, hogy a diasztereomer viszonyú izomerek egymásba alakulása közben az egyik diasztereomer folyamatosan kiválik az oldatból. Ennek a változatnak nagy elönye, hogy nem a két diasztereomer oldatbeli stabilitáskülönbsége határozza meg az egyensúlyi helyzetet, hanem a kristályosodó diasztereomer oldhatósága. Így, ha kis oldékonyságú diasztereomert sikerül előállítani, akkor gyakorlatilag a racém kiindulási anyagunk közel teljes mennyisége a hasznos izomert tartalmazó diasztereomerré alakítható. Ez már olyan hatásfok, amely miatt sok ipari kutató-fejlesztő vizsgálja a másodrendü aszimmetrikus transzformáció lehetőségét a legkülönfélébb optikailag aktív anyagok előállítása céljából. Rezolválásunk körülményei között végbemenő FGMe racemizációja ilyen eljárás hatékony kidolgozására kínált lehetőséget.

1. Táblázat. Racém 16 rezolválásának és másodrendű aszimmetrikus transzformációjának eredményei ${ }^{\mathrm{a}}$

\begin{tabular}{|c|c|c|c|c|c|}
\hline & Oldószer & $\begin{array}{c}\text { Termelés } \\
(\%)^{\mathrm{b}}\end{array}$ & $\begin{array}{c}e e \\
(\%, 16)^{c}\end{array}$ & Idő $(h)$ & $\mathrm{S}$ \\
\hline $1^{d}$ & $\mathrm{MeOH}$ & 20 & 83 & 2,5 & 0,17 \\
\hline $2^{d}$ & $\mathrm{MeOH}$ & 63 & 99 & 360 & 0,62 \\
\hline 3 & $\mathrm{Tol} / \mathrm{Ac} 10 / 3$ & 95 & 50 & 3 & 0,48 \\
\hline 4 & Tol/Ac 10/3 & 95 & 90 & 20 & 0,86 \\
\hline 5 & $\mathrm{Tol} / \mathrm{Ac} 10 / 3$ & 96 & 90 & 40 & 0,86 \\
\hline 6 & $\mathrm{Tol} / \mathrm{Ac} 10 / 4$ & 86 & 93 & 20 & 0,82 \\
\hline 7 & $\mathrm{Tol} / \mathrm{Ac} 10 / 5$ & 82 & 95 & 20 & 0,78 \\
\hline $8^{\mathrm{c}}$ & $\mathrm{Tol} / \mathrm{Ac} 10 / 5$ & 92 & 95 & 20 & 0,87 \\
\hline \multicolumn{6}{|c|}{${ }^{\mathrm{a}} \mathrm{A}$ reakciókat $0,34 \mathrm{M}$ oldatban, $40^{\circ} \mathrm{C}$ hömérsékleten végeztük. } \\
\hline \multicolumn{6}{|c|}{$\begin{array}{l}\text { 'Az ee meghatározása HPLC mérésekkel történt királis állófázisú kolonna } \\
\text { használatával (Kromasil 5-AmyCoat). } \\
{ }^{d} 25^{\circ} \mathrm{C} \text {. }\end{array}$} \\
\hline
\end{tabular}


Az oldhatósági viszonyokat optimalizálva - lehetőleg minimális legyen az oldatfázis koncentrációja a jó termelés eléréséhez, azonban a beoldódó anyag racemizációja megfelelően gyors legyen a rövid reakcióidő érdekében olyan eljárást dolgoztunk ki mellyel a racém FGMe közel egésze egyetlen enantiomerré alakítható. ${ }^{28}$ A toluol-aceton-víz elegyben elért hatásfok $\mathrm{S}=0,87$ (ee 95\%, termelés 92\%) a racém FGMe egészére nézve (7. ábra). Az aceton azon túl, hogy oldószerként funkcionál, katalitikus szerepet is játszik a másodrendủ aszimmetrikus transzformációban, ugyanis Schiff-bázis képzésen keresztül gyorsítja az oldatfázisban levő aminoészter racemizációját. A körülmények szisztematikus optimalizálása során elért eredményeket az 1. táblázatban foglaltuk össze.

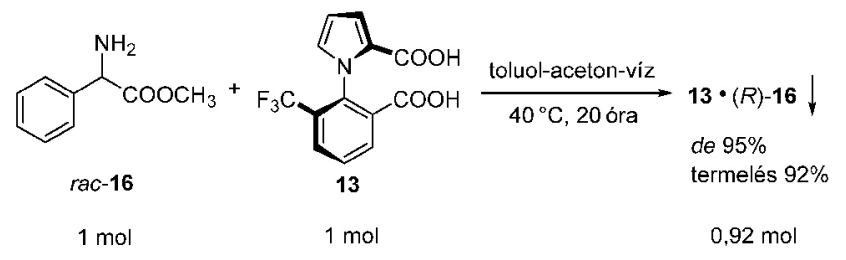

7. Ábra. Racém FGMe másodrendủ aszimmetrikus transzformációja

A fenti eredmények alapján elmondható, hogy dikarbonsav típusú atropizomer vegyületünk (13) eredményesen alkalmazható rezolválószerként; nem csak hagyományos sóképzéses rezolválásban, hanem másodrendü aszimmetrikus transzformáció megvalósítására is. ${ }^{28}$

\subsection{Enantioszelektív fémorganikus katalízis}

A vegyületek térbeli szerkezetének fontos szerepe van a különböző molekuláris kölcsönhatások megfelelő kialakulásában. Ez legjobban a gyógyszerhatóanyagreceptor kapcsolatokkal szemléltethetö, sok esetben a receptorokhoz kapcsolódó különböző térszerkezetü molekulák más-más biológiai választ idéznek elő. Többek között ez is indokolja, miért olyan nagy az igény egyszerü és könnyen megvalósítható enantioszelektív reakciók, aszimmetrikus szintézisek kifejlesztésére. Az atropizomer vegyületek egy érdekes alkalmazása az enantioszelektív reakciókban ligandumként, vagy organokatalizátorként való felhasználásuk, mely a szintetikus szerves kémia egy igen intenzíven kutatott ága. E vegyülettípus legismertebb képviselöi a BINOL és a BINAP, ${ }^{29,30}$ melyeket széles körben alkalmaznak enantioszelektív átalakítások megvalósítására. Míg C(aril)-C(aril) kötésü, axiális kiralitáselemü biarilok aszimmetrikus katalizátorkénti hasznosításának tárgyalása igen részletes az irodalomban, addig 1-fenilpirrol alapvázú atropizomer vegyületek alkalmazására eredményeink publikálása előtt nem írtak le példát.
Kutatómunkánk célja olyan bifunkciós aminolkohol ligandumok előállítása volt, melyek hatékonysága az irodalomban is vizsgált aldehidek és cinkorganikus vegyületek enantioszelektív addíciójában tanulmányozható. Az enantioszelektív fémorganikus reakció első hatékony katalizátorligandumát (19) Noyori és munkatársai publikálták ${ }^{31}$ akik munkássága nyomán az elmúlt évtizedben több, hasonló szerkezetü, többségében az amino- és alkohol-funkciókat vicinális helyzetben tartalmazó vegyületet állítottak elő szerves kémikusok (8. ábra).

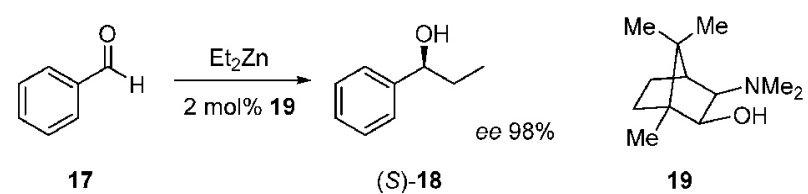

8. Ábra. Az enantioszelektív tesztreakció Noyori ligandumával

$\mathrm{Az}$ aminoalkohol típusú célvegyületek szintézisét a trifluormetil-helyettesített dikarbonsavból (13) kiindulva valósítottuk meg, mivel e vegyület optikai izomerjeinek elválasztását hatékony módszerrel tudjuk megvalósítani (6. ábra), ezáltal a forgási izomerek megfelelő mennyiségben állíthatók elő a többlépéses szintézisek megvalósításához. ${ }^{32}$ Első lépésben 13 karboxil-funkcióinak szelektív átalakítási lehetőségeit vizsgáltuk, majd a kapott aszimmetrikusan helyettesített vegyületekből további lépéseken keresztül jutottunk el primer- vagy tercier-alkohol funkciókat tartalmazó amin-származékokhoz.

A regioizomer aminoalkoholok kulcsintermedierei a 21 és 22 monoészter vegyületek. A karboxil-csoportok nagy reaktivitási különbségét kihasználva $\mathbf{1 3}$ dikarbonsav észteresítésével szelektíven a benzoesav egység reakciójával 21, ${ }^{32}$ míg a diészter-származék (20) hidrolízisével szelektíven a regioizomer 22, monoészter kapható (9. ábra). ${ }^{33} \mathrm{Az}$ optimalizált szintetikus átalakításokat kidolgozva, a funkciókat kémiailag is megkülönböztetve lehetőség nyílt a célvegyületek hatékony előállítására. A következőkben általános szintetikus átalakításokat felhasználva, szinte minden esetben kvantitatív termeléseket elérve valósítottuk meg a reakciósort (össztermelések átlagosan > 60\%). Tionil-kloridos savkloridképzést követően különböző amidokat, majd Grignard-reagensek addíciójával többféle tercier-alkohol funkciót tartalmazó származékot állítottunk elő. A célvegyületeket az amidcsoportok borános redukciójával kaptuk. Szintetikus kihívást az utolsó redukciós lépés jelentett, mivel a $\mathrm{LiAlH}_{4} \mathrm{a}$ trifluormetil funkció részleges degradációját okozta. Az előállított ligandumok között megtalálhatók alifás szekunder és tercier aminok, alifás gyürüs aminok, benzil- és

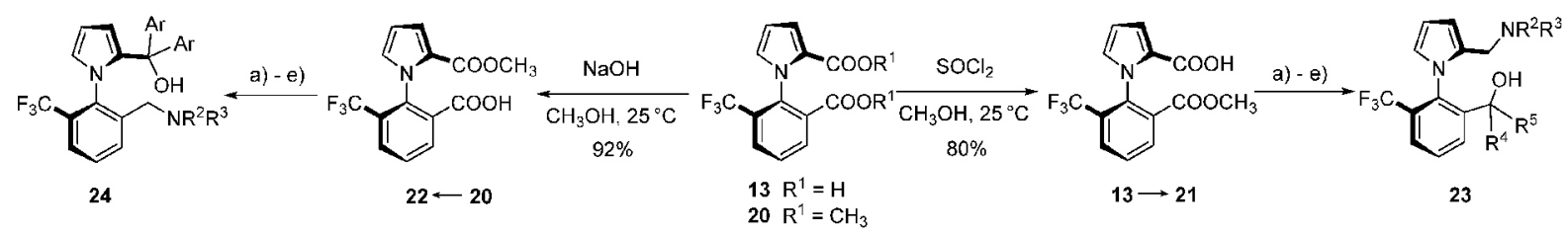

9. Ábra. A 23 és 24 regioizomer aminoalkohol ligandumok szintézise; a 21 és 22 monoészterekből kiinduló további általános szintetikus lépések: a) SOCl ${ }_{2}$, toluol, $80^{\circ} \mathrm{C}, 1$ óra; b) $\mathrm{HNR}^{2} \mathrm{R}^{3}$; c) 2 ekv. $\mathrm{ArMgBr}, \mathrm{DEE}, 0^{\circ} \mathrm{C}$, d) $\mathrm{BH}_{3} \cdot \mathrm{SMe}_{2}$, toluol, $80^{\circ} \mathrm{C}, 1$ óra; e) $\mathrm{NaOH}, \mathrm{MeOH}, 50^{\circ} \mathrm{C}, 24$ óra. 
1-fenil-etil-amin helyettesített származékok. ${ }^{32-35}$ A tercier alkohol funkciók aromás helyettesítői fenil-, ${ }^{32-34}$ illetve trifluormetil-szubsztituált ${ }^{35}$ fenilcsoportok. Célunk e származékok tesztelésével a ligandumokban lévő különböző helyettesítők sztérikus és elektronikus hatásainak tanulmányozása volt. Tericer alkohol funkciós ligandumok igen jelentős aszimmetrikus indukciót kiváltó katalizátorokat alkottak, de igen meghatározó szerepet mutatottak az atropizomer szerkezetnek amin helyettesítői. ${ }^{32-34}$ A 23 típusú aminoalkoholok első hatékony képviselöjének a pirrolidincsoportot tartalmazó 23a bizonyult. ${ }^{34}$ A modellkísérletek mindegyikében, függetlenül a benzaldehid-származék (25) szubsztituensének helyzetétől és elektronküldő, illetve szívó hatásától, kiváló termelésekkel és jó, esetenként kimagasló enantiomerfelesleggel (ee 63-95\%) kaptuk a megfelelő királis alkoholokat ((S)-26, 2. táblázat). ${ }^{34}$

2. Táblázat. A 23a ligandummal elért eredméynek különböző aldehidek és dietil-cink reakciójában

\begin{tabular}{|c|c|c|c|c|c|}
\hline & ${ }_{25}$ & 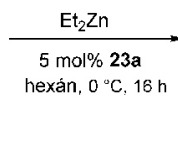 & $\overbrace{(S)-26}^{\mathrm{OH}^{H}}$ & 23a & \\
\hline & $\mathrm{R}$ & & Termelés $^{\mathrm{b}}(\%)$ & $e e^{\mathrm{c}}(\%)$ & Konf., $^{d}$ \\
\hline 1 & $\mathrm{Ph}$ & & 92 & 93 & (S) \\
\hline 2 & $2-\mathrm{Me}-$ & $-\mathrm{C}_{6} \mathrm{H}_{4}$ & 93 & 94 & (S) \\
\hline 3 & $3-\mathrm{Mc}-$ & $-\mathrm{C}_{6} \mathrm{H}_{4}$ & 94 & 93 & $(S)$ \\
\hline 4 & $4-\mathrm{Me}^{-}$ & $\mathrm{C}_{6} \mathrm{H}_{4}$ & 96 & 92 & $(S)$ \\
\hline 5 & 2-MeC & $\mathrm{O}-\mathrm{C}_{6} \mathrm{H}_{4}$ & 93 & 93 & $(S)$ \\
\hline 6 & $3-\mathrm{Mec}$ & $\mathrm{O}-\mathrm{C}_{6} \mathrm{H}_{4}$ & 92 & 93 & $(S)$ \\
\hline 7 & 4-McC & $\mathrm{O}-\mathrm{C}_{6} \mathrm{H}_{4}$ & 88 & 92 & $(S)$ \\
\hline 8 & $3-\mathrm{BnC}$ & $\mathrm{O}-4-\mathrm{MeO}-\mathrm{C}_{6} \mathrm{H}_{3}$ & 94 & $95^{\mathrm{e}}$ & $(S)$ \\
\hline 9 & $2-\mathrm{Br}^{-}$ & $-\mathrm{C}_{6} \mathrm{H}_{4}$ & 91 & 88 & (S) \\
\hline 10 & $2-\mathrm{Cl}-\mathrm{C}$ & $-\mathrm{C}_{6} \mathrm{H}_{4}$ & 92 & 90 & $(S)$ \\
\hline 11 & $2-\Gamma-C$ & & 90 & 93 & $(S)$ \\
\hline 12 & $3-\mathrm{F}-\mathrm{C}$ & & 95 & 92 & (S) \\
\hline 13 & $4-\mathrm{F}-\mathrm{C}$ & & 91 & 93 & (S) \\
\hline 14 & 1-Nap & & 93 & 90 & $(S)$ \\
\hline 15 & $2-\mathrm{Nap}$ & & 92 & 90 & $(S)$ \\
\hline 16 & $\mathrm{Ph}-\mathrm{CH}$ & $\mathrm{H}=\mathrm{CH}$ & 91 & $63^{\mathrm{e}}$ & $(S)$ \\
\hline
\end{tabular}

a A reakeiókban 3 mol ckvivalens $Z_{n} \mathrm{Et}_{2}$ reagenst használtunk.

b Izolált termelésck.

c Meghatározása GC analizissel történt (Supelco ß-DEX 120).

d Az alkoholok abszolút konfigurációjat specifikus forgatóképességük irảnya alapján, ismert irodalmi adatokkal összevetve határoztuk meg.

- Meghatározása HPLC analizissel történt (Phenomonex Cellulose-1), reakció toluolban letl végęve.

A regioizomer $\mathbf{2 4}$ szerkezetü aminoalkoholokkal elért eredmények alapján jelentős szerkezeti hatások voltak kimutathatók. Míg például dietil- és dibutil-amin szubsztituált 23-as ligandumok igen jó enantioszelektív hatást mutattak (>90\% ee) a modellreakcióban, addig a dietil- és dibutil-amin helyettesített 24-es ligandumok gyakorlatilag racém terméket eredményeztek. ${ }^{33}$ Kisebb térkitöltésü amin helyettesítőkkel - mint a pirrolidin és dimetil-amin - már a $\mathbf{2 4}$ képletü ligandumtípus jó aszimmetrikus hatása is megmutatkozott (10.ábra). ${ }^{33}$

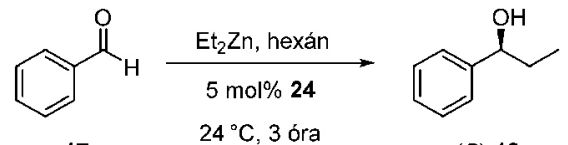

(S)-18
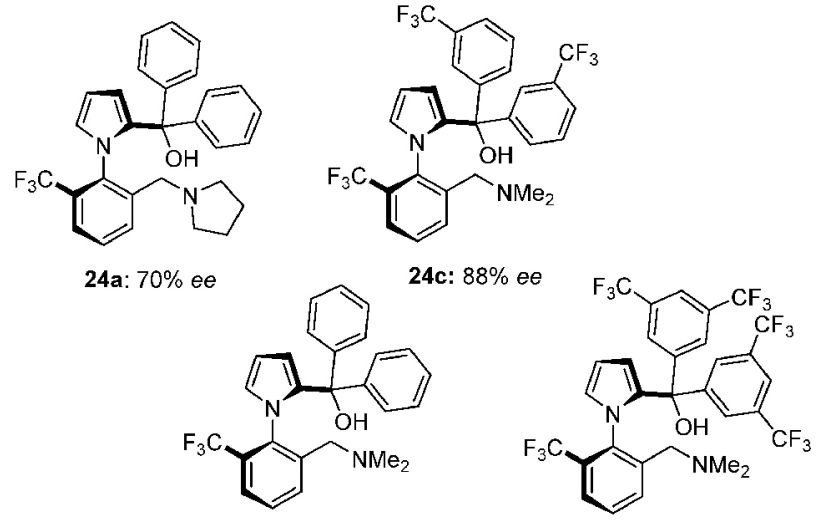

24b: $82 \%$ ee

24d: $94 \%$ ee

10. Ábra. A 24 szerkezetű ligandumokkal elért eredmények benzaldehid és dietil-cink reakciójában; vegyületszámokat követően a katalízisben előállítható 18 alkohol enantiomertisztasága látható.

Érdekes következtetések állapíthatók meg a 10. ábrán feltüntetett eredményekből. Annak ellenére, hogy a feltűntetett négy $\mathbf{2 4}$ szerkezetü ligandummal közel kvantitatív átalakítást értünk el, a királis indukciós hatásukban jelentős eltérés mutatkozott. Megállapítható, hogy e szerkezet esetében a nagy térkitöltésű nitrogén szubsztituensek jelentősen gátolják a megfelelő királis környezet kialakulását, csökkentve ezzel a kapható termék enantiomertisztaságát. Másfelől a tercier-alkohol funkció elektronikus hatásának is döntő szerepe van a megfelelö katalizátorszerkezet kialakulásában. Elektronszívó trifluormetil-csoportokkal szubsztituált ligandumok használatával jobb eredményt értünk el, 24d esetében az izolált termék enentiomertisztasága már $94 \%$ volt (10. ábra). ${ }^{35} \mathrm{~A}$ regioizomer vegyületcsalád legjobbnak talált 24d ligandumát az aldehidek szélesebb körében is teszteltük (3. táblázat), mely vizsgálatok során ugyancsak kimagasló enantioszelektivitásokat értünk el a legtöbb esetben. ${ }^{35}$

\section{3. Összefoglalás}

Az 1-aril-1H-pirrolok kémiájának kutatása során elért eredményeink a kezdeti fémorganikus funkcionalizálási vizsgálatokból kiindulva egészen addig vezette munkánkat és érdeklődésünket, hogy vegyületeinkből enantioszelektív fémorganikus átalakításokhoz használható hatékony katalizátorligandumot állítottunk elö. A kutatások döntő felismerése volt, hogy az alapvázak speciális fémorganikus reakciójával gátolt rotációjú bifunkciós atropizomerek kaphatók. A trifluormetil-helyettesített vegyület (13) funkcióinak szelektív átalakításával mindkét regioizomer aminoalkohol típusú vegyületcsaládból több képviselöt is sikeresen elöállítottunk, és eredményesen alkalmaztunk dietil-cink és aldehidek széles körének aszimmetrikus addíciójában ligandumként, példákat mutatva az általunk kifejlesztett új ligandumcsalád tagjainak hasznosíthatóságára is. 
3. Táblázat. A 24d ligandummal elért eredmények különböző aldehidek és dietil-cink reakciójában

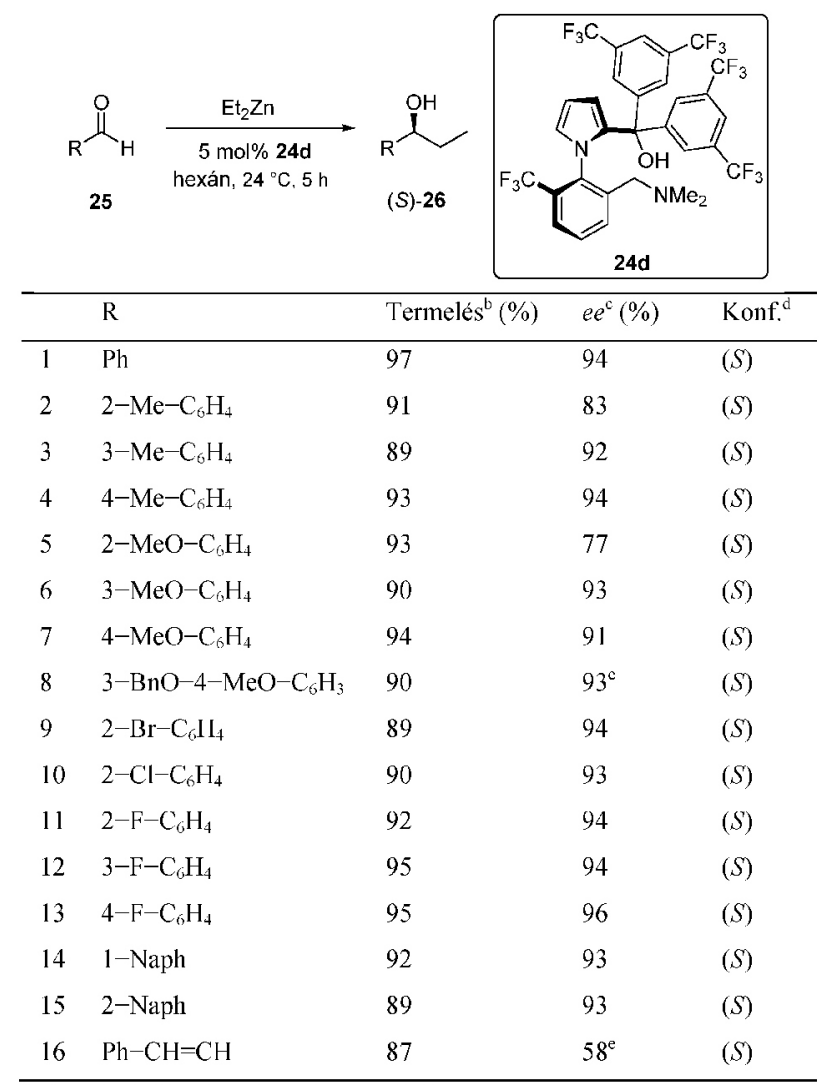

\footnotetext{
a reakciókban 3 mol ekvivalens $\mathrm{ZnEt}_{2}$ reagenst használtunk.

b Izolált termelések.

c Meghatározása GC analizissel történt (Supelco $\beta$-DEX 120).

d Az alkoholok abszolút konfigurációját specifikus forgatóképességük iránya alapján, ismert irodalmi adatokkal összevetve határoztuk meg.

e Meghatározása HPLC analízissel történt (Phenomonex Cellulose-1), reakció toluolban lett végezve.
}

\section{Köszönetnyilvánítás}

A szerzők köszönetet mondanak a kutatások anyagi támogatásáért a Nemzeti Kutatási, Fejlesztési és Innovációs Hivatalnak (K 104528 és PD 121217).

\section{Hivatkozások}

1. Tatsuta, K.; Itoh, M. J. Antibiotics 1994, 47, 602-605. https://doi.org/10.7164/antibiotics.47.602

2. Kakadiya, R.; Dong, H.; Lee, P.-C.; Kapuriya, N.; Zhang, X.; Chou, T.-C.; Lee, T.-C.; Kapuriya, K.; Shah, A.; Su, T.-L. Bioorg. Med. Chem. 2009, 17, 5614-5626. https://doi.org/10.1016/j.bmc.2009.06.018

3. Di Santo, R.; Tafi, A.; Costi, R.; Botta, M.; Artico, M.; Corelli, F.; Forte, M.; Caporuscio, F.; Angiolella, L.; Palamara, A. T. J. Med. Chem. 2005, 48, 5140-5153. https://doi.org/10.1021/jm048997u

4. Butini, S.; Brindisi, M.; Cosconati, S.; Marinelli, L.; Borrelli, G.; Coccone, S. S.; Ramunno, A.; Campiani, G.; Novellino, E.; Zanoli, S.; Samuele, A.; Giorgi, G.;
Bergamini, A.; Mattia, M. D.; Lalli, S.; Galletti, B.; Gemma, S.; Maga, G. J. Med. Chem. 2009, 52, 1224-1228. https://doi.org/10.1021/jm801395v

5. Butini, S.; Budriesi, R.; Hamon, M.; Morelli, E.; Gemma, S.; Brindisi, M.; Borrelli, G.; Novellino, E.; Fiorini, I.; Ioan, P.; Chiarini, A.; Cagnotto, A.; Mennini, T.; Fracasso, C.; Caccia, S.; Campiani, G. J. Med. Chem. 2009, 52, 6946-6950. https://doi.org/10.1021/jm901126m

6. Paillet-Loilier, M.; Fabis, F.; Lepailleur, A.; Bureau, R.; Butt-Gueulle, S.; Dauphin, F.; Delarue, C.; Vaudry, H.; Rault, S. Bioorg. Med. Chem. Lett. 2005, 15, 3753-3757. https://doi.org/10.1016/j.bmcl.2005.05.059

7. Campiani, G.; Garofalo, A.; Fiorini, I.; Botta, M.; Nacci, V.; Tafi, A.; Chiarini, A.; Budriesi, R.; Bruni, G.; Romeo, M. R. J. Med. Chem. 1995, 38, 4393-4410. https://doi.org/10.1021/jm00022a005

8. Lambelin, G.; Roba, J.; C., G.; Buu-Hoi, N. P. German Patent 1973, 2261965; Chem. Abstr. 1973, 79, 78604a.

9. Boyer, S.; Blazier, E.; Barabi, M.; Long, G.; Zaunius, G.; Wasley, J. W. F.; Hamdan, A. J. Heterocyclic Chem. 1988, $25,1003-1005$.

10. Nuss, J.; Williams, M.; Mohan, R.; Martin, R.; Wang, T.-L.; Tsuruoka, H.; Aoki, K.; Honzumi, M.; Asoh, Y.; Saito, K.; Homma, T. 2010, WO 2010/042626.

11. Campiani, G.; Nacci, V.; Fiorini, I.; De Filippis, M. P.; Garofalo, A.; Greco, G.; Novellino, E.; Williams, D. C.; Zisterer, D. M.; Woods, M. J.; Mihai, C.; Manzoni, C.; Mennini, T. J. Med. Chem. 1996, 39, 3435-3450. https://doi.org/10.1021/jm960251b

12. Schlooser, M.; Faigl, F. Tetrahedron 1994, 50, 2071-2076. https://doi.org/10.1016/S0040-4020(01)85069-9

13. Faigl, F.; Fogassy, K.; Thurner, A.; Töke, L. Tetrahedron 1997, 53, 4883-4888. https://doi.org/10.1016/S0040-4020(97)00183-X

14. Fogassy, K.; Kovács, K.; Keserü, G. M.; Tőke, L.; Faigl, F. J. Chem. Soc., Perkin Trans. 1 2001, 1039-1043. https://doi.org/10.1039/b100008j

15. Fogassy, K.; Harmat, V.; Böcskei, Z.; Tárkányi, G.; Tőke, L.; Faigl, F. Tetrahedron: Asymmetry 2000, 11, 4771-4780. https://doi.org/10.1016/S0957-4166(00)00449-3

16. Faigl, F.; Fogassy, K.; Szücs, E.; Kovács, K.; Keserü, G. M.; Harmat, V.; Böcskei, Z.; Töke, L. Tetrahedron 1999, $55,7881-7892$.

https://doi.org/10.1016/S0040-4020(99)00398-1

17. Faigl, F.; Fogassy, K.; Szántó, Z.; Lopata, A.; Tőke, L. Tetrahedron 1998, 54, 4367-4374. https://doi.org/10.1016/S0040-4020(98)00150-1

18. Faigl, F.; Thurner, A.; Vass, B. J. Chem. Res. (Synopses) 2003, 3, 132-133. https://doi.org/10.3184/030823403103173228

19. Faigl, F.; Vas-Feldhoffer, B.; Kubinyi, M.; Pál, K.; Tárkányi, G.; Czugler, M. Tetrahedron: Asymmetry 2009, 20, 98-103. https://doi.org/10.1016/j.tetasy.2009.01.010

20. Faigl, F.; Vas Feldhoffer, B.; Thurner, A. Synthethic Commun. 2006, 36, 2841-2849. https://doi.org/10.1080/00397910600770672

21. Faigl, F.; Vas-Feldhoffer, B.; Kudar, V.; Czugler, M.; Pál, K.; Kubinyi, M. Chirality 2009, 21, 905-910. https://doi.org/10.1002/chir.20686

22. Faigl, F.; Mátravölgyi, B.; Erdélyi, Zs.; Pál, K.; Hessz, D.; Kubinyi, M. Tetrahedron: Asymmetry 2010, 21, 2920-2925. https://doi.org/10.1016/j.tetasy.2010.12.005

23. Optikai izomerek elöállitása; Fogassy, E.; Ács, M.; Tőke, L., Akadémiai Kiadó: Budapest, A kémia legújabb eredményei, 1987; Vol. 65. 
24. Fogassy, E.; Nogradi, M.; Kozma, D.; Egri, G.; Palovics, E.; Kiss, V. Org. Biomol. Chem. 2006, 4, 3011-3030. https://doi.org/10.1039/B603058K

25. Faigl, F.; Fogassy, E.; Nógrádi, M.; Pálovics, E.; Schindler, J. Tetrahedron: Asymmetry 2008, 19, 519-536. https://doi.org/10.1016/j.tet.2007.11.058

26. Pálovics, E.; Schindler, J.; Faigl, F.; Fogassy, E. Tetrahedron: Asymmetry 2010, 21, 2429-2434. https://doi.org/10.1016/j.tetasy.2010.09.005

27. Faigl, F.; Fogassy, E.; Nogradi, M.; Palovics, E.; Schindler, J. Org. Biomol. Chem. 2010, 8, 947-959. https://doi.org/10.1039/b917564d

28. Faigl, F.; Mátravölgyi, B.; Holczbauer, T.; Czugler, M.; Madarász, J. Tetrahedron: Asymmetry 2011, 22, 1879-1884. https://doi.org/10.1016/j.tetasy.2011.10.021

29. Shibasaki, M.; Matsunaga, S. Chem. Soc. Rev. 2006, 35, 269-279. https://doi.org/10.1039/b506346a
30. Arshad, N.; Kappe, C. O. Advances in Heterocyclic Chemistry; Alan, R. K., Ed.; Academic Press: 2010; Vol. 99, p 33. https://doi.org/10.1016/S0065-2725(10)09902-2

31. Kitamura, M.; Okada, S.; Suga, S.; Noyori, R. J. Am. Chem. Soc. 1989, 111, 4028-4036. https://doi.org/10.1021/ja00193a040

32. Faigl, F.; Mátravölgyi, B.; Szöllősy, Á.; Czugler, M.; Tárkányi, G.; Vékey, K.; Kubinyi, M. Chirality 2012, 24, 532-542. https://doi.org/10.1002/chir.22049

33. Faigl, F.; Deák, Sz.; Erdélyi, Zs.; Holczbauer, T.; Czugler, M.; Nyerges, M.; Mátravölgyi, B. Chirality 2015, 27, 216-222. https://doi.org/10.1002/chir.22415

34. Faigl, F.; Erdélyi, Zs.; Deák, Sz.; Nyerges, M.; Mátravölgyi, B. Tetrahedron Lett. 2014, 55, 6891-6894. https://doi.org/10.1016/j.tetlet.2014.10.101

35. Deák, Sz., Mátravölgyi, B., Feczku, Gy., Erdélyi, Zs., Nyerges, M., Faigl, F. Tetrahedron: Asymmetry 2015, 26, 593-599. https://doi.org/10.1016/j.tetasy.2015.04.002

\section{Chemistry of 1-Aryl-1H-Pyrroles: from Functionalization of 1-Arylpyrrole Backbone to Enantioselective Organometallic Catalysis}

Steric arrangement of compounds has crucial role in the formation of molecular interactions. Receptor-drug interactions are illustrative examples of that fact, because the most part of the biological targets are chiral. In these cases, the different stereoisomers of a compound may cause diverse biological responses. That observation has initiated numerous research programs in order to find efficient synthetic methods for preparation of the useful pure enantiomer of a target compound. Such expectation resulted in the development of the basic methods of asymmetric synthesis. In the last 50 years dozens of chiral organometallic complexes and organocatalysts (chiral organic molecules without coordinated metal atom) have been developed and applied successfully. The phrase ,enantioselective catalysis” denote chemical syntheses in the presence of substoichiometric amount of chiral additives. One can classify these types of chemical transformations from different points of view. Depending on the fashion of asymmetric induction, asymmetric catalysis starting from prochiral compounds, kinetic resolution and dynamic kinetic resolution can be mentioned. Asymmetric catalytic reactions are usually categorized according to the type of the catalyst. It can be an enzyme, organometallic compound or metal free organomcatalyst. Chiral amino alcohol type compounds (e.g. DAIB) may be used in enantioselective addition reactions of aromatic aldehydes and diehtylzinc to produce optically active 1 -arylpropanols. ${ }^{31}$ In these reactions the in situ formed aminozincalkoxide catalyst governs the highly enantioselective addition reaction (8. ábra).

Functionalization of $\mathrm{N}$-substituted pyrroles can easily be accomplished with different electrophile reagents but the usually applied acidic conditions may cause partial degradation of the pyrrole ring. On the other hand, the electronic and steric effects of the pyrrole substituents strongly influence the position of the next substitution. Application of organolithium reagents may be a convenient solution of these problems providing efficient and regioselective routes to the target compounds. In the last 20 years, the most achievements in the metalation of substituted
1-phenyl-1H-pyrroles was achieved and published by the research group of our department. Mechanism of the lithiation of 1-phenyl-1H-pyrrole (4) was investigated and on the basis of our experimental data we postulated that dilithiation of $\mathbf{4}$ is a kinetically controlled process. ${ }^{12}$

The first efficient formation of $\mathrm{C} 2, \mathrm{C} 2$ '-dilithio-1phenyl-1H-pyrroles was accomplished by our group. Numerous new dicarboxylic acids were prepared during investigation of the metalation possibilities of 1-(substituted-phenyl)- $1 H$-pyrroles

(11, $\mathrm{R}=\mathrm{CF}_{3}$, OMe, $\mathrm{Cl}$, Me, Et, $\mathrm{Ph}$ ). ${ }^{14-16,18-21}$ One among them the most promising model compound was $\mathbf{1 3}$ which was prepared by consecutive superbase (LIC-KOR) metalation carboxylation reaction sequence and existed in racemic form due to its atropisomeric behaviour (4. ábra). Development of new resolution methods has been a permanent project at our department for several decades. ${ }^{23-27}$ Due to the special knowledge and experience of the group, several atropisomeric dicarboxylic acids were resolved via diastereoisomeric salt formation using optically active 1-phenyl-ethylamine resolving agent under different conditions (5. ábra). ${ }^{15,21,22}$ The first optically active member of our model compounds was prepared by the optical resolution of racemic 1-[2-carboxy-6-(trifluoromethyl) phenyl]-1H-pyrrole-2-carboxylic acid (13). ${ }^{15}$ A new resolution process was developed for $\mathbf{1 3}$ dicarboxylic acid using (R)-16 as new resolving agent and the optimum parameters of the diastereoisomeric salt crystallization was experimentally determined. ${ }^{28}$ It was found that the salt contains the practically pure diacid enantiomer after short (2-4 hours) crystallization time (6. ábra), but the enantiomer content of the salt gradually decreases during longer crystallization. Consequently, the efficiency of the resolution falls down during longer period of time and the salt contained only a small excess (ee $5 \%$ ) of 13 after 2 weeks crystallization (6. ábra). Series of experiments were carried out to find application possibilities of $\mathbf{1 3}$ as resolving agent. Good results were obtained during the reverse resolution of 
racemic 16. Furthermore, highly efficient thermodynamically controlled second order asymmetric transformation of $\mathbf{1 6}$ was developed with 13. This new asymmetric transformation was accomplished in a toluene/acetone/water mixture in which practically the whole amount $(92 \%)$ of racemic 16 was transformed into $(R)$-16 enantiomer (ee 95\%, 6. ábra). ${ }^{28}$

New, efficient methods were developed for the synthesis of asymmetrically substituted derivatives via selective monoesterification of the carboxylic groups of $\mathbf{1 3},{ }^{32}$ and by the selective hydrolysis of the diester $\mathbf{2 0},{ }^{33}$ producing the two regioisomeric monoester derivatives in a facile way ( 9 . ábra). Starting from 21 and 22, new amino alcohol type products were prepared with primary- and tertiary-alcohol moieties (compounds $\mathbf{2 3}$ and 24, 9. ábra). The new optically active $\mathbf{2 3}$ and $\mathbf{2 4}$ amino alcohols were tested as catalyst ligands in the addition reaction of diethylzinc and benzaldehyde, first. The effect of the structural differences of the amino alcohols on the rate of the enantioselectivity of the reaction was investigated, then preparation of $(S)$-1-phenyl-1-propanol $((S)$-18) was optimized. The best results were achieved in the presence of $\mathbf{2 3} \mathbf{a}^{34}$ (2. táblázat) and the regioisomeric trifluoromethyl substituted $\mathbf{2 4} \mathbf{d}^{35}$ (10. ábra) The highly enantioselective methods were extended to the addition reactions of aldehydes and diethylzinc (ee $58-96 \%, 2$. and 3. táblázat).

These reactions demonstrate the efficiencies of the new ligands 23a and 24d: $5 \mathrm{~mol} \%$ of this compound was enough for practically complete conversion of the aldehydes and for production of the 1-arylpropanol derivatives in high enantiomeric purities (up to 96\%). Consequently, the first, efficient members of a new, atropisomeric, 1 -aryl-1H-pyrrole type family of chiral catalyst precursors were synthetised and tested in highly enantioselective addition reactions. 